\title{
Determination of the Nutritive Values of Ziziphus Mucronata Obtained from Bagale Hills of Girei Local Government Area of Adamawa State, Nigeria.
}

\author{
${ }^{1}$ R.P. Ali, ${ }^{2}$ H.M. Maina., and ${ }^{2}$ O.O. Friday \\ ${ }^{I}$ Taraba State College of Agriculture, Department of Basic Science P.M.B 1025 Jalingo; Taraba Sate, Nigeria \\ ${ }^{2}$ ModibboAdama University of Technology, MAUTECH; School of Pure and Applied Sciences, SPAS, \\ Department of Chemistry, Yola, Adamawa State, Nigeria
}

\begin{abstract}
Determination of the nutritive values of ZiziphusMucronata was carried out. This is a fruit that enjoy wide acceptability among the inhabitants and hence the need to determine to what extent the fruit can contribute to their nutrition. Proximate analysis of the seeds revealed that protein has the highest value of $35.10 \pm 0.58$.

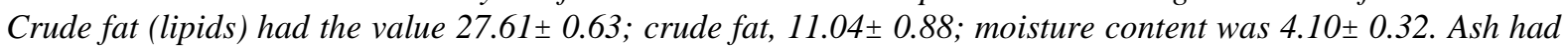
the least value of $2.85 \pm 0.23$.
\end{abstract}

Keywords: Determination, ZiziphusMucronata, Proximate, Analysis, Value

\section{Introduction}

Fruits constitute an important part of a balanced diet as they are natural source of food nutrients namely protein, carbohydrates, minerals and dietary fibres needed by man and animals. It is very important to consider our locally available fruits and to determine their nutrient composition. The powder used is used as an additive to food the seed is used for local soap, breakfast cereals and as snacks among the inhabitants (Kristosikova, 1994). They are also known to be excellent source of mineral elements (Nahar et al; 1990). The leaves of ZiziphusMucronata are also eaten by cattle, camels, goats etc. it is a seasonal fruit that grows in the semi-arid region of Nigeria and matures during the dry season.

The aim of the study is to determine the nutrient composition of buffalo thorns or ZiziphusMucronata or 'magaryankeira' (Huwale, 1985). Being a fruit that is common among the inhabitants, the need that its nutrient composition should be determined becomes very important. The study would reveal to the people how very important the fruit is in terms of its nutrient composition.

\section{Sampling and Sample Preparation}

Fruits of ZiziphusMucronata were obtained from seven different locations at Bagale Hills. The samples were mixed together and representative samples were picked at random (Asaolu and Asaolu, 2002). The sampled fruits were washed with water and rinsed with distilled water to remove the effect of surface contamination (Ahmed and Borni-Yauri, 2008). The flesh of the fruit and the seeds were separated using metal spoon after dividing the fruit into two. The seeds and the samples were grounded to fine powder using pestle and mortar. Sieving was done with a sieve of mesh size $90 \mathrm{~cm}$. The samples were packed separately in a polythene container and labelled appropriately.

\section{Analysis of the Samples}

\section{Method of Analysis}

Ash, crude fibre, crude lipid and moisture contents were determined by a method described by (Chopra and Kanwar, 1991). The crude protein was determined using micro-Kjeldahl technique, carbohydrates were determined by difference of 100 (that is, the sum of moisture, ash protein and lipids contents). The determinations were carried out in triplicates and the results were expressed as dried weight bases.

\section{Determination of Crude Protein and Nitrogen}

Crude protein and nitrogen was determined by placing $1 \mathrm{~g}$ of dried sample in a long list tube. $10 \mathrm{ml}$ of concentrated $\mathrm{H} 2 \mathrm{SO} 4$ acid and a mixture of $2 \mathrm{~g}$ of $\mathrm{K} 2 \mathrm{~S} 04$ and $\mathrm{CuS0} 4$ in 10:1 were added. The mixture was heated gently at $150^{\circ} \mathrm{C}$ for about 2 hours 30 minutes and later at $370^{\circ} \mathrm{C}$ for about 3 hours. A clear light blue solution was obtained which was allowed to cool, and then made up to $110 \mathrm{ml}$ mark with distilled water for each sample. The solution was transferred to $500 \mathrm{ml}$ Kjeldahl flask and a piece of granulated zinc was placed into the solution as $50 \mathrm{ml}$ of $40 \% \mathrm{NaOH}$ was added. A distillation apparatus was set up. $25 \mathrm{ml}$ of acid was placed in the receiving flask and it was distilled by heating the Kjeldahl flask, until two-third of the liquid has been distilled.

The distillate was titrated against $0.1 \mathrm{~N} \mathrm{NaOH}$ solution using methyl red indicator. The percentage of the crude protein was obtained according to a relationship by (Harold, 1991).

$$
\begin{aligned}
\text { Weight of Nitrogen } & =0.14\left(1-10^{-2} \mathrm{VB}\right) \\
& =0.14(1-0.001 \mathrm{VB})
\end{aligned}
$$


Where $\mathrm{VB}=$ Value of $\mathrm{NaOH}$ used,

Weight of protein

$$
\begin{array}{ll} 
& =\text { weight of nitrogen } \times 6.25 \\
& =\underline{\text { weight of protein }} \times 100
\end{array}
$$

Determination of Phosphorus

Phosphorus was determined by placing $2 \mathrm{~g}$ of the dried sample in a crucible and their placed in a furnace maintained at a temperature of $450^{\circ} \mathrm{C}$ until it was ashed. The ashed sample was removed with hot concentrated $\mathrm{HNO}_{3}$ washed and then made up to a volume of $100 \mathrm{ml}$. The mixture, $10 \mathrm{ml}$ of concentrated $\mathrm{HNO}_{3}$ and $30 \mathrm{ml}$ of molybdate solution was added gently while stirring and allowed to stay overnight. The yellow coloured precipitate of ammonium phosphomolybdate formed was collected by filtration and the precipitate was washed after decantation twice with $2 \% \mathrm{HNO}_{3}$ and then with $\mathrm{NaNO}_{3}$ solution. Finally, it was washed with $\mathrm{NaNO}_{3}$ solution over a filter paper until the filtrate was acid free as tested with a strip of litmus paper. Thereafter, it was transferred to a beaker, dissolved and the yellow precipitate was weighed. The volume of $0.1 \mathrm{NaOH}$ solution measured was then added to the excess from the burette. Phenolpthalein was used as the indicator. Excess $\mathrm{NaOH}$ was titrated with $0.1 \mathrm{~N} \mathrm{HCL}$. The percentage of phosphorus was calculated by a method described by Chopra and Kanwar (1991).

$\% \mathrm{P}=\quad$ ml of $0.1 \mathrm{~N} \mathrm{NaOH}$ used $\times 0.000135 \times$ ahliquot $\times 100$ factor

Conversion factor for phosphorous:

$$
\text { Weight of substance used }
$$

$1 \mathrm{ml}$ of $0.1 \mathrm{~N} \mathrm{NaOH}=0.0001351 \mathrm{~g}$ of $\mathrm{P}$ or $1 \mathrm{ml}$ of $0.1 \mathrm{~N} \mathrm{NaOH}=0.000309 \mathrm{~g}$ of $\mathrm{P}_{2} \mathrm{O}_{5}$

\section{Estimation of Carbohydrates and Energy Values}

Available carbohydrate was estimated by subtracting the total sum in percentage of crude protein, crude lipid, crude fibre and ash from $100 \%$ dry weight, DW of the seeds, using the relation: $100-(\%$ crude protein $+\%$ crude lipid $+\%$ crude fibre $+\%$ ash) (AOAC, 2002). The energy value (KJ) was estimated by multiplying the percentages of crude protein, crude lipid and carbohydrate by the factor is 16.7, 37.7 and 16.7 respectively, AOAC, 2002).

\section{Determination of Crude Fat (Lipid)}

The soxhlet apparatus was set up and $20 \mathrm{~g}$ of seeds, wrapped with filter paper was placed in the apparatus. $400 \mathrm{ml}$ of petroleum ether was placed in $250 \mathrm{ml}$ round bottom flask. Heating of the flask was carried out at $45^{\circ} \mathrm{C}$ to $55^{\circ} \mathrm{C}$ for about 5 hours. On completion of the extraction, the flask was disconnected and the filtrate was placed in a weighed beaker and the solvent was allowed to evaporate for two days. The weight of the beaker and fat was recorded until a constant weight was obtained. Increase in the weight of the beaker, gave the weight of the crude fat. The percentage of the crude fat was obtained from the expressed according to Harold, (1991).

$\%$ crude $\quad=$ Weight of crude fat $\times 100$

Weight of the sample

$\%$ crude $\quad=\underline{\mathrm{B}-\mathrm{BO}} \times 100$

WS

Therefore $\% \mathrm{~B}_{\mathrm{o}}=$ Weight of empty beaker, $\mathrm{B}=$ Weight of the beaker and the crude fat; $\mathrm{W}_{\mathrm{S}}=$ Weight of the sample.

\section{Determination of Crude Fibre}

$2 \mathrm{~g}$ of the sample residue obtained from lipid determination process was placed into a $100 \mathrm{ml}$ volumetric flask and $200 \mathrm{ml}$ of $1.25 \% \mathrm{H}_{2} \mathrm{SO}_{4}$ was added and was allowed to boil for 30 minutes after which it was filtered and washed with distilled water. The residue was transferred to the beaker and $200 \mathrm{ml}$ of $1.25 \% \mathrm{NaOH}$ was added and allowed to boil for 30 minutes; after which it was filtered and washed with water until it was alkali free. The residue was filtered with hot water, $1 \% \mathrm{HNO}_{3}$ was added and transferred to a weighed dish and allowed to dry to a constant weight at $100^{\circ} \mathrm{C}$. The residue was heated to ash at a temperature of $400^{\circ} \mathrm{C}$ for 2 hours and the weight recorded. The crude fibre content was calculated according to a relationship by Harold, (1991).

$\%$ crude fibre $=$ Weight of a crude fibre $\times 100$

$$
\begin{aligned}
& \text { Weight of the sample } \\
= & \frac{\mathrm{WR}-\mathrm{WA}}{\mathrm{WS}} \times 100
\end{aligned}
$$

Where WR = weight of the crucible + residue

WS = weight of the sample

$\mathrm{WA}=$ weight of the crucible + ash 


\section{Determination of Moisture Content}

$3 \mathrm{~g}$ of the sample was placed in porcelain crucible and the heated in air circulating over at $100^{\circ} \mathrm{C}$ for about 2 hours. Thereafter, the sample was cooked, weighed and reweighed until a constant weight was obtained. The percentage moisture was obtained by the expression as follows (Harold, 1991).

$\%$ moisture $=\mathrm{W}_{1}-\mathrm{W}_{2} \times 100$

$$
\mathrm{W}_{1}-\mathrm{W}_{0}
$$

Where, $\mathrm{W}_{0}$ - weight of the porcelain crucible, $\mathrm{W}_{1}=$ weight of the crucible with the wet sample. $\mathrm{W}_{2}=$ weight of the crucible and the dried sample.

\section{Determination of ash content}

$2 \mathrm{~g}$ of the oven dried sample was placed in a porcelain crucible and ignited in a muffle furnace at $350^{\circ} \mathrm{C}$ until it was grey ash in colour. The ash was allowed to cool and the weight of the ash was taken. The percentage ash was obtained according to a relationship by Harold, (1991).

$$
\% \text { Ash }=\underline{\text { Weight of ash }} \times 100
$$

Weight of sample

$$
\frac{\mathrm{M}_{2}-\mathrm{M}_{0}}{\mathrm{M}_{1}-\mathrm{M}_{0}} \times 100
$$

Where, $\mathrm{M}_{0}$ - weight of the crucible, $\mathrm{M}_{1}$ - weight of the sample and the crucible, $\mathrm{M}_{2}=$ weight of the crucible and ash.

\section{Results and Discussion}

Table 1:Proximate Composition of the seeds of ZiziphusMucronata

\begin{tabular}{ll}
\hline Parameters & Concentration (\% Dry Weight) \\
\hline Moisture & $4.10 \pm 0.32$ \\
Ash & $2.85 \pm 0.23$ \\
Protein & $35.10 \pm 0.58$ \\
Crude fibre & $11.04 \pm 0.88$ \\
Crude fat (lipids) & $27.40 \pm 0.11$ \\
Carbohydrate & $23.61 \pm 0.63$ \\
Energy KJ/100g & $1352 \pm 5.05 \mathrm{KJ} / 100$ \\
\hline The values are means and standard deviation (SD) of triplicate determination.
\end{tabular}

Source: Researcher's Findings, 2008.

The protein content of the seeds is $35.10 \pm 0.58 \%$ higher than Amaranthus SP seeds which is 10.3 to 18.3\% (Dhan and Pal, 1992), Digitarisexilis (1.3\%) and melon seed (33.8\%), Afam and Jacob (1993). The crude fibre contents and carbohydrate of ZiziphusMucronata are 11.04 0.88 and $23.61 \pm 0.63$. These values are higher than fermented melon seed with crude fibre content of $2.4 \%$ and carbohydrate with $7.3 \%$. The energy value of $100 \mathrm{~g}$ of the seeds containing $35.10 \mathrm{~g}$ of protein, $27.4 \mathrm{~g}$ of lipids and $23.6 \mathrm{~g}$ of carbohydrate is $1352.51 \mathrm{KJ}$. This exceeds the energy value of ziziphusspinachristi, with $1135.14 \mathrm{KJ} / 100 \mathrm{~g}$.

\section{Conclusion}

The fruit of ZiziphusMucronata can serve as a good source of protein, crude fat (lipid), and carbohydrate. The nutritional composition range in the following order protein $>$ crude fat (lipid) $>$ carbohydrate $>$ crude fibre $>$ moisture > ash.

\section{Recommendations}

The fruit of ZiziphusMucronata can therefore serve as a cheap source of nutrient supplementation as it is grown in the wild.

\section{Références}

[1]. Afam, I.J., Jacob, O.A. (1993) Proximate Analysis of Digestive Exilis. J. Sci. Food Agric., 63(3): Section 4.

[2]. Association of Official Analytical Chemists, AOAC, (2002). Official Methods of Analysis, 14th Edition, Association of Official Analytical Chemists, Washington DC. Arlinglein, Virginia, USA

[3]. Chopra, S.L. and Kauwar, J.S. (1991). Analytical Agricultural Chemistry, Fourth Edition Kalyani Publishers, New Delhi, India. PP. 301.Dahiru, D., Sini, J.M., and John-Africa, L. (2006) Antidiarrhoeal activity of Ziziphusmauritiana root extract in rodents. African Journal of Biotechnology. 5(10):941-945. 
[4]. Harold, E. (1991) “ Pearson's Chemical Analysis of foods. 8th Edition. PP 57, 77, 109-111.Hutchings, A., Scott, A.H., Lewis, G. \& Cunningham, A.B. (1996). Zulu medicinal plants: an inventory. University of Natal Press, Pietermaritzburg. pp. 53-54

[5]. Huwale, T.D. (1985) "Pollen Studies in ZiziphusMucronata cultivars. Aridzone J, 1:47-50.Microsoft Encarta (2009). Uses of Minerals and Vitamins in the Human Body. 1993-2008 Microsoft Corporation. All rights reserved.

[6]. Kristosikova, A.W. (1994) "National and Synthetic sweet substances". First Edition Ellis Howard Publishing Limited, PP 1-4.Nahar, N., Rahman, S., Mosiihuzzaman, M. (1990). Analysis of carbohydrates in seven edible fruits of Bangladesh. J. Sci. Food Agric. 51: 185-192. 